\title{
Poetic image of Kuzbass in the verses of regional authors
}

\author{
Dmitry Kuznetsov ${ }^{1}$, Nadezda Rabkina ${ }^{1}$, Olga Valko $^{1, *}$ \\ ${ }^{1}$ Kemerovo State University, 6 Krasnaya St., 650000, Kemerovo, Russia
}

\begin{abstract}
This research features the phenomenon of the so-called literature of space, namely amateur and professional poetic texts that together constitute a cultural supertext devoted to the Siberian coal mining region of Kuzbass. The article employed a multifaceted approach (statistical, pragmatic, textual and temporal/spatial vision analysis) to reconstruct the image of the region in the naïve worldview. Statistical analysis identified the key words and semantic models. The cognitive analysis reveals the basic cognitive structures, while the textual analysis makes it possible to reconstruct narrative and perception. The pragmatic analysis determines the communication role model and the predominant speech acts. The study exposes extended thematic nets of geographical, natural and meteorological terms, time description, and coal mining realia. The predominating cognitive models represent Kuzbass as a territory / a living being / treasure trove / home / family, while the most significant motif for professional oeuvre is legitimizing the peripheral area as an inseparable part of the Russian domain and history. Introspection, simultaneity, and strong modality appears to be the most significant text characteristics. Thus, the image of Kuzbass proves to be a complex comprehensive multitiered phenomenon based on different linguistic units and reflecting the results of the evaluative perception and processing.
\end{abstract}

\section{Introduction}

The literature of place has been of interest for linguistic and philological science for several decades. Most frequently this literature is organized around the world renowned cities (e.g. London, Dublin, Paris, SaintPetersburg, etc.), viewed as microcosms and associated with the classical authors, but may concern minor or less known places as well (e.g. Chelyabinsk, Tuapse and others) [1-4]. Summarising the explorers' observations on the city text, one may say that it makes reference to universal urban elements and reproduces specific cultural information, thus becoming highly charged with various meanings:

(1) the city in texts may embrace the elements of real and imaginary, collective and individual nature at the same time;

(2) the city text contains cultural and historical information, belonging to both past and present, which coexist in the city text;

(3) it manages to combine the great, heroic, unique with the usual, average, general;

(4) the city, as well as the city text, is a cultural generator, a collection of images, codes, interpretations and ideas.

All these make the city and consequently the city text a complex polystructural semiotic mechanism.

Alongside city texts, the literature of regions is steadily attracting attention of the researchers $[2,6,7]$. For example, Siberia and its image have been analysed in a number of works [8-9]. The image of Kuzbass was studied mostly in linguistic [10-12], but not in literary aspect.

The poetry of place is a special type of the literature of place. On the one hand, the poetry of place possesses all the characteristics and meanings enumerated for the literature of place and the city text. On the other hand, it is definitely more subjective and incomplete, as the poetry of place represents personal reaction to the city or its emotional interpretation limited by a versified form.

The images of the place, created by the literature of place, demonstrate a kind of dichotomy, as the text is likely to combine a personal perception of the place with the general or universal perception shared by the natives and / or foreigners. It is predictable for the poetic text to be more symbolic and emotional compared to the prosaic text.

Yu. M. Lotman [13], L. R. Velilaeva [14] and L. V. Almyashova [15] point at the more marked "pronominal" nature of the poetic text, as the worldview featured in poems may vary depending on the distribution of roles in it, especially as represented by the pronouns "I" or "we", "you" and "they". Choosing an individual ("I") or collective ("we") vantage point, the lyrical hero of the poem may address an interlocutor ("you") that can be his or her compatriot/s or even the region itself, describe contemporaries or predecessors ("they").

Deictic peculiarities of the text, including temporary and spatial parameters, accompany the pronominal characteristics. These parameters are quite often determined by prospective, retrospective, or simultaneous vision of the region, as well as spatial

\footnotetext{
"Corresponding author: olgav2001@gmail.com
} 
varieties of the region image: a "bird's eye view" of the region (shown with the remarkable landforms, such as mountains, rivers, lakes, valleys, etc.) or more local image (shown with the minor landscape forms, e.g. realia of the area/habitat surrounding the hero and/or encountered daily: streets, squares, buildings, plants, etc.). L. R. Velilaeva emphasises the fact that these realia may be personified and featured as the lyrical hero's friends, companions, objects of patriotic love, etc. [14]. These realia appear together with the motifs of reminiscence, walk/wandering or work, as well as entertainment at leisure in the native place.

When reproduced repeatedly in other poetic texts, realia contribute to the intertextual view of the region (world, environment, milieu). Some of the realia tend to turn into symbols or emblems of the region, thus creating cultural, literary and associative codes, and eventually building the poetic supertext of the region [5]. Common semantic fields, shared ideology, myths and values, as well as recurrent narrative patterns in the poems, serve as the evidence of the regional supertext. The collection of regional poetry is a treasure trove of valuable information for analysing geopoetics and mythopoetics of the region, prevailing conceptual models used by the natives. The poems organize and verbalize the space of the region.

As a result, the poem of the region is not only the means of self-expression, but also a way of selfidentification with the birthplace, the native place, motherland, etc. These processes are concerned with the existential issues and search for values [7]. The principal myths of the native land present it as a source of richness and fertility, power and influence, as a birthplace of heroes and talents.

\section{Material and methods}

The material analysed in the article included two sets of texts - professional texts (PT) and amateur texts (AT), devoted to Kuzbass (a region in Siberia) and written respectively by professional poets (members of literary unions or organization) and amateur ones. The texts were retrieved from the anthologies and official collections of poems, as well as from the web sites on the regional poetry, namely https://jubimaja-rodina.ru (“Любимая родина" / "Мy dear motherland" is a site accumulating poems about the native places in Russia. According to the designers of the site, they intended to help students acquaint with the literature of place).

The poetic image of the region is the linguistic reflection of life and the expression of thoughts and feelings with the help of linguistic means and stylistic devices [8]. Thus, this article strives to expose the essential elements or constituents of the image and describe the means of its creation. For this purpose, several kinds of analysis are employed. The statistical analysis is meant to identify the key words or semantic groups, which actualize semantic models associated with Kuzbass. It was carried out with the help of web services, allowing statistical text-processing. The cognitive analysis revealed principle cognitive structures and categories representing Kuzbass, including mainly cognitive metaphors, while the stylistic analysis was used to detect the expressive means highlighting the particular elements of the image. The textual analysis concentrated on narrative models and eventually exposed perception models of regional poets. The pragmatic analysis made it possible to determine the roles Kuzbass plays in the communication (the interlocutor, the addressee, the silent observer, the communication topic, etc.) and the predominant speech acts.

\section{Discussion}

The image of Kuzbass, as reproduced in the poetry, is a complex comprehensive multitiered phenomenon. Based on linguistic units of different nature, it reflects the results of the evaluative perception and processing, which seem to include a number of functions: (1) expressive (the poems present an emotional, mostly admiring, description of the place); (2) decoratively certifying (the poems manifest the region as an invariably beautiful or great place); (3) identifying (the poems establish the relations between the place and the text author); (4) unifying (the poem lets the author associate themselves with other residents of the region and express the collective opinion); (5) formative (the poems establish the perceptive and evaluative model of the region forming the world perception and mentality). The main results of the analyses are given below.

\subsection{Statistical analysis}

The sets of texts were relatively equal (Table 1): the professional poems had 2061 words, while the amateur poems had 2360 words. The statistical analysis discovered that the vocabulary of the professional texts was richer than that of amateurs (974 and 879 unique words, respectively).

Table 1. Statistical characteristics of the PT and the AT

\begin{tabular}{|c|c|c|}
\hline & PT & AT \\
\hline Word number & 2,061 & 2,360 \\
\hline $\begin{array}{c}\text { Character } \\
\text { number }\end{array}$ & 10,233 & 11,439 \\
\hline $\begin{array}{c}\text { Unique word } \\
\text { count }\end{array}$ & 974 & 879 \\
\hline $\begin{array}{c}\text { Core word } \\
\text { count }\end{array}$ & 910 & 816 \\
\hline
\end{tabular}

It is quite expected that 'Кузбасс' / 'Kuzbass' turned out to be the most frequent word in both sets, used 38 times in PP and 61 times in AT, which made up 1.8\% and $2.6 \%$ of occurrences in the collections, respectively (Tables 2 and 3 ). 
Table 2. The top 10 words in the PT

\begin{tabular}{|c|c|c|c|}
\hline & Tokens & $\begin{array}{c}\text { Relative } \\
\text { frequency, } \\
\%\end{array}$ & $\begin{array}{c}\text { Relative } \\
\text { frequency in } \\
\text { the core, \% }\end{array}$ \\
\hline $\begin{array}{c}\text { 'Кузбасc' / } \\
\text { 'Kuzbass' }\end{array}$ & 38 & 1.8 & 4.2 \\
\hline $\begin{array}{c}\text { 'земля' / } \\
\text { 'land' }\end{array}$ & 18 & 0.9 & 2.0 \\
\hline $\begin{array}{c}\text { 'человек' / } \\
\text { 'man' }\end{array}$ & 14 & 0.7 & 1.5 \\
\hline $\begin{array}{c}\text { 'свой' / } \\
\text { 'ошn' }\end{array}$ & 14 & 0.7 & 1.5 \\
\hline $\begin{array}{c}\text { 'сердце' / } \\
\text { 'hеart' }\end{array}$ & 14 & 0.7 & 1.5 \\
\hline $\begin{array}{c}\text { 'Сибирь'/ } \\
\text { 'Siberia' }\end{array}$ & 13 & 0.6 & 1.4 \\
\hline $\begin{array}{c}\text { 'край' / 'area, } \\
\text { region' }\end{array}$ & 13 & 0.6 & 1.4 \\
\hline $\begin{array}{c}\text { 'мелодия'/ } \\
\text { 'теlody' }\end{array}$ & 11 & 0.5 & 1.2 \\
\hline $\begin{array}{c}\text { 'жить' / } \\
\text { 'live' }\end{array}$ & 9 & 0.4 & 1.0 \\
\hline $\begin{array}{c}\text { 'мыть' / 'jig' } \\
\text { (1) }\end{array}$ & 9 & 0.4 & \\
\hline
\end{tabular}

Table 3. The top 10 words in the AT

\begin{tabular}{|c|c|c|c|}
\hline & Tokens & $\begin{array}{c}\text { Relative } \\
\text { frequency, } \\
\% \\
\end{array}$ & $\begin{array}{c}\text { Relative } \\
\text { frequency in } \\
\text { the core, } \%\end{array}$ \\
\hline $\begin{array}{l}\text { 'Кузбасс' / } \\
\text { 'Kuzbass' }\end{array}$ & 61 & 2.6 & 7.5 \\
\hline $\begin{array}{l}\text { 'родной' / } \\
\text { 'native' }\end{array}$ & 24 & 1.0 & 2.9 \\
\hline $\begin{array}{l}\text { ‘край' / 'area, } \\
\text { region' }\end{array}$ & 20 & 0.8 & 2.5 \\
\hline 'мыть' / ‘jig' & 19 & 0.8 & 2.3 \\
\hline $\begin{array}{l}\text { ‘уголь' / } \\
\text { 'coal' }\end{array}$ & 18 & 0.8 & 2.2 \\
\hline $\begin{array}{l}\text { ‘твой’ / } \\
\text { 'your' }\end{array}$ & 14 & 0.6 & 1.7 \\
\hline $\begin{array}{l}\text { ‘жизнь' / } \\
\text { 'life' }\end{array}$ & 11 & 0.5 & 1.3 \\
\hline $\begin{array}{l}\text { 'земля' / } \\
\text { 'land'' }\end{array}$ & 11 & 0.5 & 1.3 \\
\hline $\begin{array}{l}\text { ‘леса' / } \\
\text { 'woods' }\end{array}$ & 10 & 0.4 & 1.2 \\
\hline $\begin{array}{l}\text { ‘дом’' } \\
\text { 'home' }\end{array}$ & 10 & 0.4 & 1.2 \\
\hline
\end{tabular}

Besides, the PT and AT expose a number of other correlations demonstrating the categorizing results in a number of semantic models (Tables 2 and 3 ).

Firstly, both sets of poems actualize the main cognitive model, anchored in the speakers' minds, "Kuzbass is a territory", as PT and AT contain generic notions 'земля' / 'land' (used 18 times in PT and 11 times in AT, which makes up $0.9 \%$ and $0.5 \%$ of occurrences) and 'край' / 'area, region' (used 13 times in PT and 20 times in AT, which makes up $0.6 \%$ and $0.8 \%$ of occurrences). Thus, the PT tend to feature Kuzbass as an entity, such as a realm or domain in Siberia (11 tokens, $0.6 \%$ ); whereas the AT emphasize its divisional nature and relation to the population (their belonging to it by birth - 'родной край' / 'native region') from the point of view of its function or role for the individual ('дом' / 'home' - 10 tokens, 0.4\%). Secondly, both sets make reference to an existential aspect of the region - "Kuzbass is a place I / we live in" - though by dissimilar morphological units. The PT contain verbs 'жumb' / 'live' (9 tokens, 0.4\%), the AT contain nouns 'жизнь' / 'life' (11 tokens, 0.5\%). Thirdly, both sets highlight the economic specialization of the region - "Kuzbass is a mining region", as both sets have the verb 'Mblmb' / 'jig' (used 9 times in PT and 19 times in AT, which makes up $0.4 \%$ and $0.8 \%$ of word occurrences). The verb refers to a technological process in mining, i.e. separating coal or ore by means of a wirebottomed sieve moved up and down in water. In the AT this model is more pronounced owing to the word 'уголь' / 'coal' (18 tokens, 0.8\%) resulting in the collocation.

[8] stated that factors forming the image of the Eastern Siberia included geographical and climatic peculiarities, multiconfessional and multiethnic nature, and historic stereotype featuring Siberia as a place of exile and a penal colony. Due to the affinity of the images of Siberia and Kuzbass, these categories were chosen as a starting point for the analysis of the vocabularies and thematic groups describing Kuzbass in the regional texts. The analysis was supplemented by the assessment and description of the following semantic groups: coal mining vocabulary (standing for the staple industry of the region), abstract nouns (representing the abstract notions and values associated with the region) and evaluative adjectives (functioning as means of assessment).

Table 4. Thematic groups of vocabularies in the PT and AT

\begin{tabular}{|c|c|c|}
\hline & PT & AT \\
\hline geography & $200 / 21 \%$ & $116 / 13 \%$ \\
\hline $\begin{array}{c}\text { climate and } \\
\text { weather }\end{array}$ & $32 / 3 \%$ & $42 / 5 \%$ \\
\hline $\begin{array}{c}\text { coal-mining } \\
\text { abstract } \\
\text { nouns }\end{array}$ & $48 / 5 \%$ & $39 / 4 \%$ \\
\hline $\begin{array}{c}\text { evaluative } \\
\text { adjectives }\end{array}$ & $109 / 11 \%$ & $123 / 14 \%$ \\
\hline
\end{tabular}

These thematic groups are the main means of exploring the elements that express author's / speaker's world perception and mentality, which in their turn are able to form or influence the reader's / recipient's world 
perception and mentality, focusing on the chosen elements of the world image.

The vocabulary featuring geography and nature persists (fields, taiga, mountains, sand, cedar, forest leek, deer, beaver, bear, birds' song, moose, etc.). However, amateur poets seem to feel obliged to enumerate all they know about the territory they live on, whereas professional poets are able to select the most important features and give a description in wider brushstrokes.

The PT and AT meet the expectation concerning the usage of words about climatic and weather conditions (32 tokens, 3\% and 42 tokens, 5\%, respectively); however the PT are more focused on winter and cold (16 tokens) than the AT are (4 tokens).

Alongside with an extended thematic net of geographical, natural and meteorological terms, there is a system of time description. In a way, Kuzbass time is cyclic: it is an ever-changing but eternal circle of year and daily rhythms, the vicissitude of seasons and dawns. In spite of extreme contrasts of freezing winters and hot, sultry summers, the authors' estimates are positive and inspiring.

The other significant thematic net is related to mining and industrial terms: gallery, beams, methane, cage, tonnes of coal, face, seam, metal, metallurgy, etc. It is quite predictable, since Kuzbass is known mostly for its coal industry, which shapes all aspects of the local community life, from urbanonyms to education [16]. It is no wonder the local residents live in constant contact with various coal mining realia, which enter their thesaurus. The list of local onyms is rather short. It includes the Shoria district, plant names, and the name of the former governor.

Abstract nouns constitute a considerable share of the vocabulary of the poems in the PT and the AT $(8 \%$ and $10 \%$ respectively) and are marked by versatility.

In terms of geography and space, the PT and AT demonstrate the only match 'nростор, размах' / 'expanse, range', sustained by 'uирота, щuрь' / 'vastness' in the AT and further modified there: 'высота' / 'height, altitude', 'космос' / 'space', 'окраина' / 'outskirts, fringe', 'оплот' / 'bulwark', 'nрирода' / 'nature'; 'тишина' / 'silence'. The PT provides 'приют' / 'shelter'.

Historic and temporal characteristics of existence are set down in both the PT and AT with the words 'время' / 'time', 'поколение' / 'generation' and 'судьба, доля' / 'destiny, lot', which allows one to see history in a human groups' aspect as predetermined successions of the events. However, the PT underline the contrast between the transient given moment and the previous periods or the scope of the history: 'данность' / 'presence', 'мгновение' / 'moment', 'реальность' / 'reality', 'cтарина' / 'olden time', 'эnоха' / 'epoch'. The AT emphasize the personal nature of time and history: 'детство' / 'childhood', 'ностальгия' / 'nostalgia', 'праздник' / 'holiday', 'традиция' / 'tradition', 'череда' / 'sequence'.

The philosophical and ethical terms are more varied in the PT, serving the evidence of the meditative and reflective nature of the professional poetry. The terms concurrent in the PT and AT establish the eternal duality 'бог' / 'god' and 'dyx, душа' / 'spirit, soul'. The PT specify it with the abstract terms 'благо, добро' / 'good, goodness', 'благодарность' / 'gratitude', 'вера' / 'faith', 'чудо' / 'wonder, miracle'.

The general abstract notions differ as well. They only overlap in 'красота, краса, прикраса' / 'beauty, adornment, embellishment' and 'сила' / 'power', featuring the principal positive characteristics of the region (beautiful and powerful). Partial coincidence can be seen in 'осознание' / 'realization' (vs 'знание' / 'knowledge', which are related in Russian and nominate different stages of cognition, and in 'могущество' / 'might, potency' vs 'мousb' / 'might, power'. Other abstract nouns in the PT describe objective parameters 'мера' / 'mеаsure', 'порядок' / 'order', 'связь' / 'connection', 'система' / 'system', 'состояние' / 'condition'. The AT focus on less homogeneous terms demonstrating evaluative slant: 'блеск' / 'splendor', 'великолепие' / 'magnificence', 'величие' / 'grandeur', 'скопление' / 'concentration', 'смена' / 'change', 'условие' / 'condition' and others.

Quite a big number of abstract nouns have to do with the human activity, representing it either as labour (mpyd / labour, усилие / effort, переделка / alternation, перестройка / rebuilding in the РТ; долг / duty, напор / energy (go), работа / work, строительство / construction work in the AT) or act of creation (вдохновение / inspiration, талант / talent, творчество / creation in the $\mathrm{PT}$, and дap / gift, стремление / striving in the AT). The human activity is also described in terms of planning (мотив, желание, стремление, план, цель) and results (победа, подвиг, прибыль, удача, успех, награда, закалка).

The professional and amateur poems let a recipient judge about the personal and/or private life of Kuzbass residents. It is characterized by various feelings and states, mainly 'гордость' / 'pride', 'любовь' / 'love', 'мечта' / 'dream', 'paдость' / 'joy', 'cyacmbe' / 'happiness', which obviously outline the principal values and life priorities for them. Not concurrent notions include 'восторг' / 'delight, rapture', 'здоровье' / 'health', 'комфорт' / 'comfort', 'честь' / 'honour', 'чистота' / 'purity' in the PT and 'доблесть' / 'valour, heroism', 'достоинство' / 'dignity', 'мудрость' / 'wisdom', 'надежда' / 'hоре', 'нежность' / 'tenderness', 'нрав' / 'temperament', 'стойкость'/ 'endurance', 'удовольствие' / 'pleasure', 'ум' / 'intellect' in the AT. The abstract nouns in the AT demonstrate a wider range of semantics which can be explained by a more individual and emotional nature of the texts.

The social and political categories also exert themselves in the PT and the AT, though not that extensively. Firstly, both poems make references to the motherland/fatherland (отчизна, держава, родина) actualizing the idea of Kuzbass being a part of Russia. Secondly, the texts reflect different characteristics of the community and aspects of living in the society (власть, дружба, забота, право, признание, свобода слава, совет, согласие, союз, стабильность, суд, язык, слово and others). 
The number of negative abstract nouns is commensurate ( 12 for the PT and 11 for the AT). The matching nouns are 'горе' / 'grief' and 'сомнение' / 'doubt', posing the question about this selection of abstract terms. Featuring the more global and crucial phenomena is expectedly realized in the PT: 'бремя' / 'burden', 'война' / 'war', 'година' / 'calamitous time', 'кризис' / 'crisis', 'потеря' / 'loss', 'провал' / 'failure', 'nycmoma' / 'emptiness', 'cyровость' / 'severity'. The AT depict negative phenomena from a more personal angle: 'беда' / 'misfortune', 'боль' / 'pain', 'невзгода' / 'adversity', 'ненастье' / 'bad weather', 'проблема' / 'problem', 'сожаление' / 'regret'.

Evaluative adjective tend to retain the tendency discovered for the abstract nouns, with the PT emphasizing the scope and the grandeur of the events (барско-иарский, всесильный, державный, небостремительный, неисчислимый, размашистый, священныци, еtс.) and the AT focusing on the individual aspects of the perception (благодарный, благодатный, близкий, добрый, долгожданныц̆, достойный, душевный, знакомылй, любимылй, маленькая, мальій, мильій, нужныци, приятный, сердечный, уважаемый, еtс.).

\subsection{Cognitive and stylistic analyses}

The PT and AT make it possible to reproduce the cognitive models representing Kuzbass in natives' minds. However, the AT offer an insight into naïve worldview. People devoid of pencraft resort to poetry as a means of self-expression when they are overwhelmed with emotions. A similar impulse caused British soldiers of the Great War to fall back on poetry not to lose their mind in the trenches. Schooled in Homer, Virgil, and classical poetry, they produced what later became gems of world poetry. In the post-Gutenberg epoch, Internet users often appeal to poetry to sublimate negative emotions they receive from the outer world [17] or give vent to delights or patriotic raptures.

However, English-speaking authors would often produce better quality amateur oeuvre since they stick to blank verse and simple language use. Russian amateur poets believe that the language of poetry is as alien to common speech as possible. The laws of classical Russian versification come into contradiction with poor word choice, clichés, and trite stylistic devices. As it seems, Kuzbass citizens that produce odes to the region wish to let out inner exaltation induced by some outer event - an anniversary or a public holiday.

The cognitive structures representing Kuzbass can vary according to the information highlighted and contents actualized [18]. Besides, they adapt to the context, focusing on the particular part of the image of Kuzbass. Most poetic contexts demonstrate that the image of the region is built in a hierarchical system consisting of the macroconcept (the cognitive structure that represents a larger entity including the region), the concept (the cognitive structure that represents the region itself) and the microconcept (the cognitive structure that represents the constituents of the region) [3].

The previous section demonstrated that the poetic text provides the evidence of various perceptions and interpretations of the reality. If the diction has a more individual status, illustrating the way the speaker verbalizes their ideas, metaphors, and especially cognitive metaphors, are more fixed due to their reproducibility and have a collective nature, showing how the group categorizes and construes the reality.

Both PT and AT verbalize numerous cognitive metaphors. The most frequent among the concurrent metaphors is that of personification: KUZBASS AS A LIVING BEING or ITS PART. Amateur authors personify the land as an epic "bogatyr" (warrior) with a great soul and a mighty heart, whose veins run with coal (6 cases). Hence, enemies of Kuzbass are cannibals, and methane gas is a dangerous living creature, etc. Capitalizing the personal pronoun "he" heightens the author's admiration. Professionals emphasize the magnitude of Kuzbass' actions: it rises from its knees, squares its shoulders, strides forward, presents its talent to the people, and receives decoration for combat heroism.

The widely "marketed" image of Kuzbass includes the one of a heart ( 2 cases): Kuzbass is a mighty heart on the map of Siberia (inter alia, its outline actually is heartshaped). Therefore, the region is the vital organ of the whole country, sine qua non: it is an irreplaceable engine and, at the same time, a shield. In Russian linguoculture, heart is a vessel of feelings, emotions, and thoughts; it can foretell the future and it guides the whole body.

The authors may feature Kuzbass as a suffering creature, as its body is covered with the rash of coal open-cuts and lacerated wounds of coal strip mines, making the lyrical hero plead for forgiveness and promise to lay them down with flowers.

Another concurrent metaphor is KUZBASS AS HOME, especially home for numerous nations, which are thoroughly enumerated in some poems. The AT depict Kuzbass as a large home with enough space for everyone ( 3 cases). A similar attitude depicts Kuzbass as a family where towns are brothers and the Tom River is the mother ( 3 cases). The PT complement this image with the reference to intergenerational continuity: Kuzbass is the (fore)fathers' land, thus a native place, home. This metaphor is made more complex owing to the allusions to the Babylonian confusion ('после вавилонского дробленья') and historically turbulent years ('золотая каторга моя', 'арены Кузбасса', etc.). After these historic aberrations, citizens of Kuzbass long for peace and reunion, homelike atmosphere.

Finally, there is the metaphor showing KUZBASS AS A TREASURE TROVE of Russia (4 cases). The metaphors are extended but trite and adopted mostly from patriotic songs (e.g. Kuzbass is a pearl of Siberia, Kuzbass stores - a glut of wealth, Kuzbass' vast expanses, etc.). Similarly, coal is referred to as black gold or heat and energy. Epithets are hackneyed as well, e.g., green forests, ancient trees, white snow, high mountains, strong winds, etc. Kuzbass' description looks as if borrowed from a Wikipedia article or a tourist 
booklet: it is a land of weather extremes with a vast taiga, rye and wheat fields, chamomile meadows, crystal clear rivers, etc.

There is one distinct motif that is typical of professional poetry and very seldom appears in amateur verses. It is the motif of periphery. Kuzbass is located on the edge of the Russian oecumene (on the other side of the Urals; far away in Siberia, contrasted to Moscow and the Volga basin, etc.); thus, its link to the main land should be legitimized, which authors feel obliged to do.

Less striking are sparsely scattered metaphors likening Kuzbass to activities and states ('Кузбасс - это подвиг' / 'Kuzbass is a heroic deed'; 'Кузбасс - это светится сердце шахтёра' / 'Kuzbass is a miner's heart afire', etc.).

Professional poetry reveals only one case of a more or less authentic metaphor: KUZBASS AS A SHIP. The region is compared to a vessel that nearly sank during the Perestroika but survived due to the heroic efforts of its people.

Another characteristic feature is that professional poets are more authentic in adopting Slavic mythology the aspect that in amateur poetry is limited to trite epic formulae. Kuzbass is described as a paradise where streets flow with milk and honey, and the water is sweet Professional poets also use some authentic images typical of old Russian fairy-tales or XIX century satire, like The Yellow-Bellied Gudgeon by M. Ye. SaltykovShchedrin, etc. For instance, one poem features black fish with a pick axe of a fin and an anglerfish-like mining light - the only fish that can survive in the frozen ice-mine of a river. Nobody knows if the fish truly exists, but if it ever finds dynamite, everyone will find out, which is probably an allusion to the miners' strikes when Kuzbass made headlines of central newspapers.

Professional poems are nearly as short of stylistic devices as amateur oeuvre. Professional poets employ personification ( 5 cases). Kuzbass is a real man: like its many miners, Kuzbass does not care about his own health, and the numerous open pits are gaping wounds or scars on his body. Kuzbass is definitely a male image, not only due to the grammatical gender of the word itself, but mostly due to its identification with its heroic residents, i.e. coal miners, and coal mining remains a male job.

Not only is Kuzbass on the frontier of the populated universe, its main life goes underground. Coal miners descend into the bowels of the earth and ascend on a daily basis. Most mythologies place the world of the dead underground, as opposed to the human realm. Every day coal miners complete the sacral act previously ascribed to the gods and mighty heroes of the epic past, e.g. the Sumerian descent of Inana to the nether world; Egyptian sun-god Ra; Greek Orpheus, etc. Ultimately, it is the Biblical motif of the Anastasis, or the descent to hell. Hence the main pathos of coal mining is the sacrifice: miners give their lives for light and warmth, which are the traditional attributes of life as opposed to death.

In heathen, shamanic tradition, shuttling between the world of the dead and the world of the living is the prerogative right of shamans, people with special powers. A single trip to the underground realm turns the visitor into an alien in the world of the living; that is why in traditional cultures witch doctors and their kind tend to live on the outskirts of settlements. From this point of view, the peripheral location of the region is a sign that marks its special, nearly mystic character.

Another analogue can be found in the key concept of the frontier in American linguoculture that largely shaped the worldview of its people and the national literature. The frontier means wilderness - hence the threadbare geographical lists, which fix the area in the conceptual body of Russia and turn its residents into pioneers. All Kuzbass people are identified by what they do, i.e. coal mining. They are epic characters since iron runs in their veins.

The motif of sacrifice fixes the region not only in space but also in time: it is during World War II that local people gave their lives to protect the country by descending into coal mines or by going to war "to the West". Siberia is a multinational Babylon, a paradox land world famous as a place of exile and no return but where serfdom never reached, the land of the free.

\subsection{Textual analysis}

Prospection and retrospection belong to the grammatical category of the space-time continuum, which is a certain sequence of facts/events unfolding in time and space. Referring to the past or future, the time of narration also changes the place of action. Introspection is also, above all, a spatial phenomenon. The character for a while comes out of the space where they acted together with other characters, and delves into the individual space of their inner world. A distinctive feature of introspection is that the space in which the action takes place is the consciousness of the character.

As a textual category, retrospection involves a purposeful action on the part of the author, who, turning mentally to the past and describing past events, seeks to direct the reader's attention to the facts that may be fundamental to the disclosure of the basic idea of the whole work. Being a categorical sign of retrospection, temporal shifts that violate the linear sequence of events define the complex unity of diverse and heterogeneous elements, interconnected and interacting with each other.

Prospection is a grammatical category of the text, combining various linguistic forms of content-factual information attribution to what is regarded as possible, (un)desirable or imminently forthcoming. As well as retrospection, prospection gives the reader an opportunity to imagine the connection and significance of the most important episodes in the oeuvre.

The difference between retrospection and prospection may be described as follows: retrospection always takes some place in the progressive movement of the text, whereas prospection is rarely caused by the very course of the plot development.

Retrospection has a more precise and specific nature of penetration into temporal layers of the narrative as compared to prospection. In retrospective display of events, the author often refers the reader to a certain 
period of time from the life of the character, whose duration or remoteness from the events underlying the storyline, receives an explicit expression through time indicators, while prospective temporary transfer is often fuzzy, blurred. In other words, the reader is transferred to the future in very general terms, without it being limited to specific time frames. It is to be emphasized once again that prospection and retrospection are analyzed primarily as elements of the artistic time, not the artistic space.

It is obvious that prospection and retrospection correlate in a certain way with introspection. The main point of contact is that all the three phenomena relate to the inner reality of the character. Memories and appeals to future events are realized only in the consciousness of the character. Logically, the question arises whether all cases of prospection and retrospection can be considered as cases of introspection altogether due to the fact that they all recreate the inner world of the character, describe the movement of their thoughts and mental leaps from one time context to another.

In certain cases, despite the fact that the action takes place in the inner reality of the character, all the memories relate to the event plan, not to the plan of experiences, sensations and internal assessments of the character. The character simply moves along the axis of time, passing thoughts into the past. At the same time, the space in which the action takes place changes. However, it is not the internal space of the character but quite a real physical space in which some events took place in the past. An absolutely different picture is observed in other contexts, where emotional state comes out of the real, physical world and enters the world of feelings and sensations in the inner mental and emotional space. In both cases we are dealing with retrospection, but only in the second case with introspection.

Thus, introspection intersects with retrospection but it is narrower than the latter.

It is important to note that introspection, coupled with retrospection, is associated not only with reconstruction of the emotional state of the character, but also with the intellectual assessment of their past actions.

It is somewhat more difficult to establish the correlation between introspection and prospection, as the future is more subjective than the past.

The subjectivity of events and phenomena in the future lies in the fact that the speaker in many cases defines the future as reality that does not depend on external conditions or as something desired, assumed, dependent on circumstances [19]. According to George Leech, any prediction has a modal connotation, since the speaker cannot be sure of the future to the extent that they are sure of the past or the present [20]. Thus, the concept of future is considered to be more abstract than the concepts of present and past which means that it is more closely related to the modal meanings of desirability, necessity, (un)reality of an upcoming or anticipated action. Moreover, the very concept of future as a category of probabilistic inherent modality of potentiality, hypothetical action. This feature of the future time is pointed out by many researchers. The specificity of the modal value of the future is that it always makes the communicated message to some extent hypothetical, problematic, considered as quite feasible, but still it is not reality, it is only expected or assumed.

In other words, even when planning future concrete actions, a person is in the sphere of subjective assessment of possibility and desirability, which allows attributing a greater number of cases of prospection to introspection at the same time.

Thus, a general conclusion can be made that prospection and retrospection intersect with introspection, but do not coincide completely. The main criteria that allow distinguishing between introspection and retrospection or introspection and prospection are the following: taking into account a) the event plan; and b) the spatial parameter, that is, consideration of the space in which the action takes place. If the real physical space in which some events occur is fixed, then such contexts can be referred to as prospection or retrospection. If possibility or desirability of future events, future or past emotional state of the character or the assessment of past events is presupposed, here we deal not only with prospection or retrospection but also introspection.

From the point of view of textual categories, the analysis of the poems shows obvious difference in terms of time referencing and employing the modality aspect between the oeuvres of professional writers and amateurs.

With little exception, simultaneity and introspection seem to be the most wanted among the professionals: they are more likely to consider the situation described as belonging to the deictic 'here and now', meanwhile being ready to contribute to the sights given back or to the future.

The "looking-back-sight" is mostly associated with the "Golden Age" of Kuzbass locality or, even more likely, with the respect for the achievements and feats of the past generations, whereas the "looking-forward" trend expects wishes and goals yet to be achieved.

The cohesion of Kuzbass poetic supertext is ensured by a few conventional precepts and more or less unanimous estimates and attitudes. They permeate text recurrently, with varying degree of detail. Mostly, the estimates, given to the achievements of the past are limited to the times of World War II. More rarely - to the more modern or more distant times.

Kuzbass is naturally regarded as a source and provider of armor, coke, chemical substances and, most importantly, people - heroes, fighters, warriors.

Naturally, the professional authors of the lyrics share the conventional outlook: "We are proud to have been here, to have participated, to have invested into our great victory, into the further development of our homeland..."

Modality status is very acute here. The "social order", the principle, which dominated in this country for dozens of years, has remained predominant. Therefore, the treatment of the events of the past, which remains rather quirky, is subject to consideration.

In the PT introspection plays a much less significant role than that in the works of the amateurs. Suffice it to say that professional authors resort to analyzing their 
personal feelings and attitudes five/six times more rarely than the amateur writers do.

Anyway, the amateur writers tend to create specific kinds of oeuvres, very much different from those created by professionals [21].

The focus is mostly fixed on "me/myself and how I feel in this environment". Amateur writers mostly get fixed on their own perception of the outward reality, concentrating on their personal perception of what is going on. Introspective links play a very important role in their discourse, connecting inner world / perceptions / affiliations to reality.

More than that, introspection seems to be the main idea of their writing, giving assessment to what they personally - experienced and somehow reflected in their writings.

What is more, the amateur writings often have an anthem-like quality. Be it intentional or not, it can't but be felt. The rhyming, the diction, the choice of syntactic structures - all these contribute to the perception of a lyrical piece as a manifest, a "what's to be done", which, of course, is quite impressive.

\subsection{Pragmatic analysis}

Pragmatic peculiarities of the PT and the AT may be assessed from the point of view of the communicative situation and through the speech acts employed in the texts.

Table 5. Occurrences of the communication parameters in the $\mathrm{PT}$ and the AT

\begin{tabular}{|c|c|c|}
\hline & PT & AT \\
\hline I-narration & $24 \%$ & $72 \%$ \\
\hline we-narration & $65 \%$ & $66 \%$ \\
\hline $\begin{array}{c}\text { Kuzbass as an } \\
\text { addressee }\end{array}$ & $29 \%$ & $62 \%$ \\
\hline $\begin{array}{c}\text { other people } \\
\text { as addressees }\end{array}$ & $24 \%$ & $17 \%$ \\
\hline
\end{tabular}

The current analysis considered the communicative situation established by the poems and found out that only a small part of the texts demonstrates the impersonal mode of narration. The poet associated with the lyrical hero quite often associates themselves with an individual or collective author, choosing respectively "Inarration" or "we-narration" (see Table 5). Both modes are not self-exclusive, as starting with one, the speaker may shift to the other. As can be expected, the AT demonstrate an overwhelming preference of "Inarration" ( $72 \%$ of poems, compared to the occurrence of "I-narration" in $24 \%$ of the PT), once again demonstrating the individual-centred and emotionfocused nature of the amateur poetry. The commensurate engagement of the "we-narration" in the texts $(65 \%$ for the PT and $66 \%$ for the AT) only evidentiates that the lyrical heroes can hardly separate themselves from the regional population. Thus, the region contributes to not only its residents' self-identification, but also their unity.

As mentioned above, the lyrical hero of the poem may choose an interlocutor and address him / her / them ("you"). The fact that the lyrical hero associates with their compatriot/s prevents them from addressing or appealing to them $(24 \%$ of poems in the PT or $17 \%$ of poems in the AT). On the contrary, quite frequently the lyrical hero chooses to address Kuzbass, making it their own interlocutor. Surprising as it may seem, the amateur authors tend to do it twice as often as the professional authors (62\% vs. $29 \%)$, resulting in a more personal and intimate kind of relations due to endowing the region with human features.

The speech act analysis enables the researcher to see in more detail the types of relations between the interlocutors. Kuzbass being the main subject-matter of the poems explains the omnipresent status of the representatives (also known as constatives and assertives). They are used to state the factual information about Kuzbass.

Other speech acts fall into declaratives (formal statements of one's beliefs or feelings), commissives / promissives (making a commitment or giving a promise), directives (giving an order, command or instruction) and expressive sociative speech acts (including addressives / appealatives, greeting, parting, apology, well-wishing and gratitude).

Table 6. Occurrences of the speech acts in the PT and the AT

\begin{tabular}{|c|c|c|}
\hline & PT & AT \\
\hline declaratives & $29 \%$ & $27 \%$ \\
\hline $\begin{array}{c}\text { commissives / } \\
\text { promissives }\end{array}$ & $24 \%$ & $35 \%$ \\
\hline directives & $29 \%$ & $28 \%$ \\
\hline Expressive sociative speech acts \\
\hline $\begin{array}{c}\text { addressives / } \\
\text { appealatives }\end{array}$ & $35 \%$ & $59 \%$ \\
\hline greeting & $6 \%$ & $0 \%$ \\
\hline parting & $6 \%$ & $0 \%$ \\
\hline apology & $6 \%$ & $0 \%$ \\
\hline well-wishing & $18 \%$ & $21 \%$ \\
\hline gratitude & $0 \%$ & $28 \%$ \\
\hline
\end{tabular}

As can be seen from the table, declaratives, commissives / promissives and directives account for approximately one third of the poems in both groups. Moreover, declaratives are used to announce about the lyrical hero's pride or love towards the region; commissives / promissives serve to express the lyrical 
hero's intention to stay with his / her region, take care of it, continue its traditions, etc.; directives can be addressed to Kuzbass (e.g., 'живи и процветай' / 'live and prosper') or to the compatriots (e.g., 'И ты Кузбассу помоги!' / 'Help Kuzbass!') with the urge to keep up traditions, work on or improve the situation. All said above allows to conclude that the regional poetic texts are called in the first place to tell readers about the region and/or its personal image, and in the second place to express oneself and induce others' actions.

The distribution of the expressive sociative speech acts in the texts reinforces the statement about a more personal and intimate kind of relations between the lyrical hero and the region in the AT. It results in 59\% of AT having direct address or appeal to the region, $28 \%$ of AT expressing gratitude and $21 \%$ of AT wishing it well.

\section{Conclusion}

The results of the analysis show that the image of Kuzbass, be it reproduced in the high-flown poetry of acknowledged authors, or hackneyed, more banal and crude versions of amateurs, coming 'from the depth' of public perception, is a complex comprehensive multilateral phenomenon. Obviously, the choice of language varies greatly, opening (at least) two different paradigms for those creating and perceiving the oeuvres.

The data presented above unequivocally proclaim that - being a toponym - 'Kuzbass' features in the local discourse as a form of supertextual phenomenon, bearing a paramount semiotic value. Moreover, allusive components, references to the same events of Kuzbass history have a distinctive drive towards creating a cultural supertext.

For the people of Kuzbass, the everyday feat of spending a quarter of a life underground is mundane. This is something that finds place in both PTs and ATs. Professional poets, however, tend to regard this as a heroic sacrifice, while amateurs are more likely to speak of the mining labor as banal work for the sake and benefit of the country, promising a better future for one and all.

Both professional and amateur writers unanimously see Kuzbass as a living being. It's noteworthy that amateurs mostly perceive this living being as a sort of endangered species; professionals are more inclined to see the positive sides: strength, might, benevolence, etc., while amateurs tend to see the region as a blessed, but mightily abused; promised, but underestimated land. This seems to be a sort of crucial difference, which (as will be mentioned later) allows professionals to see the brightest future for their land.

The time context seems to be of crucial importance for both groups of writers. Moreover, a similarly important role belongs to the personal (mental/spiritual) link between the writer and the homeland.

However, there's a significant difference. While professionals are very much more likely to allude to the past deeds of the predecessors, modally charging their feats and - wilfully or not - appropriating the good that the latter did, thus obtaining the cause for pride and self- esteem, amateurs express their hopes for the better future. That's why quite a part of professional poetry sounds somewhat sinister, relaying the disasters / hardships / misfortunes of the past, while amateurs in their oeuvres are (overly-)optimistic and tend to expect only the best for their homeland.

It is worthwhile to emphasize the semiotic nature of the image of Kuzbass. The toponym 'Kuzbass' not only nominates the region, but also organizes all kinds of information (conceptual, factual, associative, symbolic, operational, etc.) related to the proper name into cognitive structures, which can be actualized in communication in a form of texts, thus contributing to semiosis of the onym. The speaker / author 'unfolds' the sign, selectively explicating it and withdrawing related information. The texts in their turn also can function as a sign, especially if considered together as a cultural supertext.

\section{References}

1. A. V. Shubina, Izvestia: Herzen University Journal of Humanities \& Science. 96, 228-231 (2009).

2. V. G. Shevchuk, Scientific Notes of Crimea Federal V.I. Vernadsky University, 1 (67), vol. 3, 172-182 (2015).

3. T. A. Sirotkina, Regional Onomastics: Issues and Prospects, 276-278 (2016).

4. E. A. Smyshlyaev, Literature as a Form of Social and Indivifual Reflection: Proceedings of XIX AllRussian Science and Practice Conference of Philologists, 144-149 (2016).

5. E. A. Smyshlyaev, New Philology Bulletin, 2 (45), 236-246 (2018).

6. V. M. Mokienko, Quaestio Rossica, 2, vol. 5, 552566 (2017).

7. N. V. Barkovstaya, A. Grominova, Philology Class, 4 (46), 27-35 (2016).

8. E. S. Manzyreva, Bulletin of Kemerovo State University of Culture and Arts, 38, 33-39 (2017).

9. I. V. Saveleva, N. V. Melnik, Journal of Siberian Federal University. Humanities \& Social Sciences, 12(1), 137-154 (2019).

10. O. N. Kondratieva, Psycholinguistics in contemporary aspect - 2018. Proceedings of XIII International Science and Practice Conference, 126129 (2018).

11. O. N. Kondratieva, Proceedings of the International Conference: Learning to Understand Russia: Political and Mass Media Communication, 132-134 (2018).

12. O. N. Kondratieva, T. I. Frolova, Psycholinguistics: Science and practice collection of articles, 24-2, 7897 (2018).

13. Yu. M. Lotman, Struktura khudozhestvennogo teksta [Structure of the literary text]. (1972).

14. L. R. Velilaeva, TSPU Bulletin, 7 (184), 160-163 (2017). 
15. L. V. Almyasheva, Scientific Digest: Humanitarian Studies, 11, 183-188 (2016).

16. E. Marinova, N. Rabkina, M. Ryabova, O. Valko, E3S Web Conf. IIIrd International Innovative Mining Symposium, 41 (2018).

17. N. V. Rabkina, Concept WAR in English language war poetry. Cand.Phil.Sci. (2008).
18. O. V. Valko, Nauchnyy dialog, 4, 21-42 (2018).

19. D. V. Kuznetsov, Philologicheskiye Nauki, 5, 50-59 (2007).

20. G. Leech, Meaning and the English Verb (1971).

21. Yu. V. Shatin, Critic and Semiotics, 2, 89-100 (2018). 